\title{
Ownership Structure and Corporate Governance and Its Effects on Performance: A Case of Selected Banks in Kenya
}

\author{
Eric Ernest Mang'unyi \\ Department of Research, The Catholic University of Eastern Africa \\ P.O. Box 62157-00200, Nairobi, Kenya \\ Tel: +254-722-973-630 Email: mangunyie@gmail.com,mangunyie@yahoo.com
}

Received: May 16, 2011 Accepted: July 21, 2011 doi:10.5430/ijba.v2n3p2

\begin{abstract}
This study explored ownership structure and corporate governance and its effects on performance of firms in Kenya with reference to banks. The study revealed that there was no significant difference between type of ownership and financial performance, and between banks ownership structure and corporate governance practices. Further results revealed that there was significant difference between corporate governance and financial performance of banks. However, foreign-owned banks had slightly better performance than domestically-owned banks. This study recommends that corporate entities should promote corporate governance to send a positive signal to potential investors. The Central Bank of Kenya (CBK) should continue enforcing and encouraging firms to adhere to good corporate governance for financial institutions for efficiency and effectiveness. Finally, regulatory agencies including the government should promote and socialise corporate governance and its relationship to firm performance across industries.
\end{abstract}

Keywords: Corporate Governance, Ownership Structure.

\section{Introduction}

Tandelilin et al., (2007) asserts that the central focus in most literature around, discussion analysis in research all over the world on matters to do with corporate governance has been the role of ownership structure as a corporate governance mechanism. Whether the kind of ownership structure matters and what are its implications for corporate governance are areas that raise some concern (Tandelilin et al., 2007). A lot of attention has focused on the relationship between ownership structure and corporation performance for instance a rich research agenda on the implications of ownership structure on corporate governance by La Porta et al. (2000) affirm that when the legal structure does not offer sufficient protection for outside investors and entrepreneurs, original owners are forced to maintain large positions in their companies which result in a concentrated form of ownership thus having implications on ownership structure. On the other hand, bulk of the evidence according to Shirley and Walsh (2001) indicates that privately held firms are more efficient and more profitable than publicly held ones although the evidence differs on the relative merit of the identity of each private owner.

In 1976, Jensen and Meckling provided results of their researches on ownership structure and firm performance by dividing shareholders into internal investors with management right and external shareholders who are investors without ballot right. The conclusion of their research was that value of the firm depends on the internal shareholder's share, which is called ownership structure.

In Kenya, financial reforms have encouraged foreign banks to enter and expand banking operations in the country. Kamau (2009) affirm that foreign banks are more efficient than local banks. She attributes this to the fact that foreign banks concentrate mainly in major towns and target corporate customers, whereas large local banks spread their activities more widely across the country. Foreign banks therefore refrain from retail banking to specialise in corporate products, while large domestic banks are less discriminatory in their business strategy. These different operational modalities affect efficiency and profitability she notes.

Studies with regard to corporate governance theme have mainly been carried out in developed economies mostly in the United Kingdom and the United States of America with few afore mentioned being done in Africa and specifically Kenya. However, the concept of governance in Kenya is now increasingly being embraced knowing that it leads to sustainable growth and more so, since Kenya has had a history of poor governance system in the banking industry attributed to weak corporate governance practices, lack of internal controls, weaknesses in regulatory and supervisory systems, insider lending and conflict of interest which led to the collapse of many financial institutions with others going 
under receivership (Centre for Corporate Governance (CCG), 2004). Measures have been put in place by institutions such as Central Bank of Kenya, Capital Markets Authority and Centre for Corporate Governance to champion the cause of good corporate governance. However, despite all these measures, the problem of corporate governance still remains unresolved. It is in the light of the above, that this study therefore sought to study ownership structure and corporate governance and its effects on performance in the banking industry in Kenya.

\subsection{Statement of the Problem}

Global events concerning high-profile corporate failures have put back on the policy agenda and intensified debate on the efficacy of corporate governance mechanisms as a means of increasing firm performance (Sanda et al., 2005). Since the beginning of the 21 st century, serious financial scandals and many cases of corporate mismanagement brought about an increasing attention to corporate governance, in a close relation with business ethics issues. In academic literature, as well as in public policy debates, corporate governance is nowadays acknowledged as a critical factor in economic development and financial markets stability the researchers affirm (Sanda et al., 2005).

Despite tight regulatory framework, corporate governance continues to weaken in Kenya. Much needs to be done to sort out this mess otherwise we are likely to see more corporate failures and malfunctions in the region. There has been renewed interest concerning issues of corporate governance in Kenya, however, relevant data from empirical studies are still few and far between. This has invariably led to limitations in the depth of our understanding of corporate governance issues. Performance of firms in the recent past has witnessed relatively poor results for example, financial results falling below desired targets. Besides that, corporate governance has been characterized by highly concentrated ownership, low ownership share of foreign owners, high ownership and decision making power in the hands of the state owned and relatively low ownership shares in the hands of insiders. Thus, some investors lacked clout to make significant impact on corporate governance. Hence, what are the effects of ownership structure and corporate governance on performance? It is on this basis that the study sought to establish the effects of ownership structure and corporate governance on performance. How does ownership structure and corporate governance relate to firm performance and what effects does ownership structure have on corporate governance and performance of a firm?

\subsection{The Research Questions}

The study sought to answer the following questions:

a) What are the different ownership structures of banks in Kenya?

b) What is the relationship between ownership structure and corporate governance?

c) What is the relationship between ownership structure and performance?

d) What is the relationship between corporate governance and performance?

\subsection{Study Hypotheses}

To offer useful answers to the research questions and realize the study objectives, the following hypotheses stated in their null forms were tested.

\subsubsection{Null Hypothesis 1}

There is no significant difference between banks ownership structure and corporate governance practices in Kenya.

\subsubsection{Null Hypothesis 2}

There is no significant difference between banks ownership structure and financial performance

\subsubsection{Null Hypothesis 3}

There is no significant difference between corporate governance and financial performance.

\subsection{Conceptual Framework}

In order to bring to light the effects of ownership structure on corporate governance and performance in the banking sector, the study attempted to isolate the key variables underpinning the study thus; ownership structure specifically type of ownership, the institutions' corporate governance practices and return on assets and return on equity as the key performance variables as demonstrated in Figure 1.

In the conceptual framework model (figure 1), it is assumed that various types of ownership structure have a direct influence on corporate governance. In turn corporate governance affects performance activities in a different way. Thus, the type of ownership of a bank will affect its corporate governance for instance, the board size which may be large or small, leadership for instance split of chair and CEO, audit independence, board composition i.e. proportion of inside 
and outside directors etc. Corporate governance in turn affect performance of the firm for example, board size can affect financial performance of the bank. If the board size is too big, this may interfere with the decision making process for instance of the financial structure of the organization like share ownership, capital injection or ratio of equity ownership. On overall, this will have an effect on the financial performance of the firm e.g. there may be evidence of decrease in earnings per share (EPS) which may imply that the firm is not performing well in the stock market hence decreasing stock price. Reduced resource utilization meaning resources are not fully utilized to the set or required capacities. Customer expectations may not be met or fulfilled leading to poor sales and services and increased complaints from the customers. The market share and/or position may change to either become bigger or shrink. Competitive advantage of the firm may also be overtaken by its competitors.

\section{Literature Review}

The subject of corporate governance in Kenya has been top of the agenda for many years. Despite tight regulatory framework, corporate governance continues to weaken in Kenya to some extent. Kenya in particular, concern was raised specifically on the way in which organizations were managed and controlled. According to Centre for Corporate Governance of Kenya (CCG) (2004), focus on corporate governance in the financial sector is crucial mostly because the banking industry became highly exposed to scrutiny by the public and many lessons were learnt because of the risks involved including adverse publicity brought about by failings in governance and stakeholder relations for instance, the collapse of banks such as Euro bank, Trust bank and Daima bank just to mention a few cases (CCG, 2004). The study further affirms that funding of banks as well as ownership of other companies is a crucial issue for management of banks as these makes them a significant stakeholder in their own right. It was also observed that governance in banks is a considerable more complex issue than in other sectors. This is because banks try to comply with same codes of good governance as other firms but factors like internal control, capital adequacy and funding, risk management and compliance all have an impact on their matrix of governance.

According to Blair (1995) issues in corporate governance revolve around ownership and control. She asserts that companies need to experiment with different governance arrangements, such as choosing directors to represent particular constituencies, or making more radical arrangements like leveraged buyouts or worker-owned companies. More so, public policy should encourage, or at least not impede, such experimentation. Blair goes on to state that 'ownership of private property is the central mechanism by which incentives are created for the efficient use of resources in a free market economy'. Although numerous individuals from suppliers to employees have a stake in the success of companies, the strategic decisions are made by the Corporate Executives (Nambiro, 2007). Thus, the main puzzle in corporate governance is how do you make these executives accountable to the shareholders whose investment is at risk, while still giving them the freedom, the incentives and the control over the resources they need to create and seize investment opportunities and to be tough competitors (Nambiro, 2007). She further gives a number of mechanisms used to align the interests of the executives and those of the shareholders which include but not limited to boards of directors, executive compensation, active use of ownership prerogatives by large shareholders like institutional investors (internal mechanisms) and the market for corporate control like acquisitions (external mechanisms).

\subsection{Ownership Structure as an Internal Governance Mechanism}

Zhuang (1999) argue that ownership structure is one of the most important factors in shaping the corporate governance system of any country. This is because it determines the nature of the agency problem. That is, whether the dominant conflict is between managers and shareholders, or between controlling and minority shareholders. Zhuang identified two important aspects of corporate ownership structure as concentration and composition. According to him, the degree of ownership concentration in a firm determines how power is distributed between its shareholders and managers. When ownership is dispersed, shareholding control tends to be weak because of poor shareholder monitoring the author affirms. For instance, a small shareholder is unlikely to be interested in monitoring because he/she would bear all the costs of monitoring hence share a small proportion of the benefits (Zhuang, 1999). This raises the question, what if all small shareholders behave this way. Then no monitoring of managerial efforts would take place. Zhuang further argues that when ownership of a company is concentrated, large shareholders would play an important role to monitor the management. However, he says that the only problem with this form of ownership is how minority shareholders would be protected from exploitation by controlling shareholders who may act in their own interests at their expense. Secondly, ownership composition tries to define who the shareholders are and who among them belongs to the controlling groups.

It can be assumed that better overlap between ownership and control should indeed lead to a reduction in conflicts of interest therefore higher firm value (Holderness, 2009). He further states that it can be complicated when looking at how ownership, control and firm value are related. For example, management owning a company can serve to better put in line managers' interests with those of the shareholders of the company. On the other hand, if managers and shareholders' 
interests are not completely aligned, higher stake in the company can give managers greater freedom to pursue their own goals without fear of reprisal. Hence, the effect of managerial ownership on the value of the firm depends on the trade-off between the alignment and entrenchment effects (Denis \& McConnell, 2002).

\subsection{Linkage between Corporate Governance and Bank Performance}

According to Tandelilin et al. (2007) managers and owners of banks showing efforts and intention to implement good corporate governance increase market credibility and subsequently collect funds at lower cost and risk. It can be argued that better corporate governance will lead to high performance (Tandelilin et al., 2007). This is supported by an empirical study done by La Porta et al. (2002) on firms' performance from 27 developed countries Evidence from their findings showed that there is higher valuation of firms in countries with better protection of minority shareholders.

In an attempt to shed more light on the link between corporate governance and firm performance, Coleman (2007) did a study in Africa targeting 103 listed firms on Ghanaian, Nigerian, Kenyan and South African stock exchanges. The findings of the study indicate that large and independent boards enhance firm value and that when a CEO serves as board chair, it has negative effect on performance and such firms employ less debt. He also found that a CEO's tenure in office enhances firms' profitability while board activity intensity has a negative effect on firm profitability. The study also revealed that while larger boards employ more debts, the independence of a board has a significant negative relationship with short-term debt. Further, the researcher notes that the size of audit committees and the frequency of their meetings have a positive influence on market-based performance measures and institutional shareholding essentially sends a positive signal to potential investors thereby enhancing market valuation of firms (Coleman, 2007).

\subsection{Linkage between Ownership Structure and Firm Performance}

In Kenya financial reforms have encouraged foreign banks to enter and expand banking operations in the country. Kamau (2009) affirm that foreign banks are more efficient than local banks. She attributes this to the fact that foreign banks concentrate mainly in major towns and target corporate customers, whereas large local banks spread their activities more widely across the country. Foreign banks therefore refrain from retail banking to specialise in corporate products, while large domestic banks are less discriminatory in their business strategy. These different operational modalities affect efficiency and profitability she affirms.

\subsection{Corporate Governance System in Kenya}

Kenya's corporate governance system was highly influenced by two factors: after the government relaxed rules that governed issuance of licenses to banks in 1982 and by the privatisation process that began in the 1980's and gained momentum in the 90's. This led to the growth of many banks that did not put into practice proper corporate governance structures resulting into poor governance and management culture in the industry (CCG, 2004). A case in point was it the year 1984 when the Rural Urban Credit Finance was placed in interim liquidation.

The Government of Kenya through the Central Bank made changes in the Central Bank act and the banking act to curb instability in the banking industry. This was for example, through raising the capital requirements and the creation of the Depositors Protection Fund. Regardless of efforts made to streamline the banking sector, many banks have been liquidated or put under receivership. The collapse was due to weak internal controls, poor governance and management practices. For example, Continental Bank of Kenya and Continental Credit Finance Ltd collapsed in 1986. In 1987 Capital Finance went under. The Government then formed Consolidated Bank by merging seven banks that had collapsed (Nambiro, 2007).

Various reasons were given that may have contributed to the collapse of banking institutions in Kenya. The Centre for Corporate Governance, (2004) outlined the following reasons as being major contributors to this phenomenon; insider lending and conflict of interest, weaknesses in regulatory and supervisory systems, poor risk management strategies, lack of internal controls and weak corporate governance practices. This followed by the Central Bank of Kenya to outline more bold and elaborate measures to curb these problems and also to strengthen its arm of supervisory role it plays in the industry.

Corporate governance in the banking sector in Kenya largely relates to the responsibility conferred to and discharged by the various entities and persons responsible for and concerned with the prudent management of the financial sector (Central Bank of Kenya, 2006). The corporate governance stakeholders in the banking sector include the board of directors, management, shareholders, Central Bank of Kenya, external auditors and Capital markets Authority (CCG, 2004). 


\subsection{Corporate Governance of State, Foreign and Locally Owned Financial Institutions in Kenya}

According to the guideline on corporate governance as stipulated in the Central Bank of Kenya (CBK) prudential guidelines of (2006) for institutions licensed under the banking act Cap 488, an institution is required to have non-executive director who is not involved in the day-to-day management and not a full-time salaried employee of a banking institution or of its subsidiaries. In addition, it is a requirement that it has an independent non-executive director who is not employed by the institution in an executive capacity within the last five and does not have any conflicting interests with the institution. However, no shareholder with more than five percent $(5 \%)$ shareholding in a banking institution is supposed to be an executive director or form part of the management of the institution or institution's holding company. On the same note, no director and chief executive officer is required to take up a position before he/she is cleared by the central bank and that the directors of the institutions shall control the manner in which the business is conducted i.e. corporate planning, effective functioning of board and management committees in key areas, set-up an effective internal audit department and compliance function, maintain adequate capital base among others (CBK Prudential Guidelines, 2006).

As concerns the Board of Directors for each institution, the guidelines stipulate that the board is responsible for formulating policies, procedures and guidelines concerning duties, responsibilities and code of conduct of its officers. Relevant board committees are constituted to assist the board and its directors in discharging the duties and responsibilities. In order to achieve the necessary balance, CBK requires all institutions' board to have at least five directors, three-fifths of whom should be non-executive Directors. This is because of banks special nature of deposit-taking giving them an added responsibility of safeguarding the interests of the depositors. Similarly, independent non-executive directors comprise the majority of the non-executive directors serving on the board to ensure that the non-executive directors, who form the majority, render the necessary independence to the board from the executive arm of the banking institutions, and help mitigate any possible conflict of interest between the policy-making process and the day-to-day management of the institution.

In the increasingly complex banking environment, the presence of suitably qualified independent directors can contribute effectively towards achieving the main tasks of the board (CBK Prudential Guidelines, 2006). Further, independent directors are required to provide the necessary checks and balances on the board of the institution so as to ensure that the interests of minority shareholders and general public are given due consideration in the decision-making process. Independent directors are not supposed to be brought in as a mere formality as this would be tantamount to deceiving the minority shareholders and the public.

As concerns foreign banks, CBK Prudential Guidelines (2006) stipulate that formation of local Committees is a requirement. This specifically applies to their branches, which need to have at least five members in their local committees whose responsibilities are similar to those of the Board of Directors. On multiple directorships, an individual is not allowed to hold the position of a director in more than two institutions licensed under the Banking Act unless those institutions are subsidiaries or holding companies. However, government bodies represented in institutions' boards by virtue of their position as government bodies are exempted. The Chairman of the board is supposed to be a non-executive director the guidelines state. On conflict of interest, directors, chief executive officers and management are not allowed to engage directly or indirectly in any business activity that competes or conflicts with the institution's interest such as outside financial interest, other business interests, employment and corporate directorship (CBK Prudential Guidelines, 2006).

\subsection{Review of Theories}

This section reviews some of the corporate governance theories with a view to understand how they relate to governance. Several theories exist that attempt to highlight the objective of the firm and how the firm should be responsible in meeting its obligations. This study looked at four main theories that have influenced corporate governance development as shown in (Figure 2).

\subsubsection{Principal-agent Theory}

It has been argued that the agency theory has been the most dominant issue in corporate governance and the principal-agent theory is generally considered the starting point of this debate. Agency theory hypothesises that in the modern corporation, in which share ownership is widely held, managerial actions depart from those required to maximise shareholder returns (Mallin, 2007).

\subsubsection{Stewardship Theory}

Stewardship theory offers an alternative to agency theory by suggesting that when a convergence of values exists between principals and agents or when organisations promote unselfish values, responsible behaviour results by internal 
means (Dicke, 2000). Lack of trust referred to by the agency theory regarding authority and ethical behaviour is what is replaced by this theory which is one of the key distinguishing features of it (Donaldson \& Davis, 1991).

\subsubsection{Stakeholder Theory}

According to Freeman et al. (2004), stakeholder theory basically aims at striking a balance between the interests of a corporation's stakeholders and their satisfaction. It tries to identify the purpose of the firm. Identification of the firm's purpose therefore becomes the driving force underlying its activities (Freeman et al., 2004). By highlighting the firm's responsibility to its stakeholders, the author states that it pushes the management to design and employ appropriate methodologies to determine the nature of the relationship between interested parties and the management in order to deliver on their purpose. Freeman further says that there is a realization that economic value is created by people who voluntarily come together, cooperate and hence improve everyone's circumstances (Freeman et al., 2004).

\subsubsection{Transaction Cost Economics}

According to Mallin (2007), Transaction Cost Economics (TCE) theory though closely related to agency theory views the firm as a governance structure. She notes that certain economic benefits to the firm exits when a firm undertakes transactions internally rather than external. Mallin further states that in its turn, the firm becomes larger, the more transactions it undertakes and will expand up to the point where it becomes cheaper or more efficient for the transaction to be undertaken externally. Stiles and Taylor (2001) point out that this theory is concerned with managerial discretion and it assumes that managers are given to self-interest seeking and moral hazard and that they operate under bounded rationality. The theory also regards the board of directors as an instrument of control hence, managers will tend to sacrifice rather than maximise profit of course not being in the interests of shareholders just like the agency theory (Mallin, 2007).

\subsection{Knowledge Gap}

Many other researchers have examined the relationship between variety of governance mechanisms and firm performance. However, the results are mixed. Some examine only the impact of one governance mechanism on performance, while others investigate the influence of several mechanisms together on performance. There is a yawning gap that exists since none of them covers effects of ownership structure on corporate governance and performance specifically in the commercial banking sector in Kenya. The only study done in Kenya by the Centre for Corporate Governance focussed on governance practices in the commercial banking sector in Kenya. More so, the many unpublished work done in Kenya followed suit by focusing corporate governance in general with only one study among them focussing on the relationship between implementation level of Capital Markets Authority guidelines on corporate governance and profitability of companies listed at the Nairobi Stock Exchange (NSE). It is against this background that the researcher found it necessary to carry out a study on ownership structure and corporate governance and its effects on performance in the Kenyan commercial banking sector to bridge the gap that exist.

\section{The Research Design and Methodology}

In order to look at the ownership structure and corporate governance and its effects on performance in the Kenyan commercial banking sector, a survey design was used. The population of the study comprised of banks within Nairobi City in Kenya. Stratified sampling was employed to select the banks. A total of 40 bank managers drawn from state-owned, locally-owned and foreign-owned banking institutions selected through purposive sampling procedure participated in the study. The stratification of the sample allowed for diversity of views and statistical analysis.

A semi-structured questionnaire consisting of both closed and open-ended questions was used. The questionnaire was personally administered to the bank managers to collect primary data from the selected banks. Descriptive ways of Statistical Package for Social Sciences (SPSS) were used to analyze the data into frequencies and percentages. One-way Analysis of Variance (ANOVA) was used to test the hypotheses.

\subsection{Reliability and Validity of Instruments}

This survey used Alpha $-\alpha$ (Cronbach), the model for internal consistency based on average inter-item correlation to test scaled items. Brown (2002) indicates that Cronbach's alpha reliability coefficient normally ranges between 0 (if no variance is consistent) and 1 (if all variance is consistent). The closer the coefficient is to 1.0 the greater the internal consistency of the items in the scale. An alpha $(\alpha)$ score of 0.70 or higher is considered satisfactory (Gliem and Gliem, 2003). All reliability tests had Cronbach's Alphas of higher than 0.7. The results suggest that all items had higher than minimum requirement of Alpha. As concerns validity, the researcher gave the questionnaire to two experts in business research to look at them independently for content validity. Their suggestions on the content and structure were then included to improve the final draft of the instrument. 


\section{The Research Findings}

The first research question sought to establish the type of bank ownership structure that exists in order to find out the representation of the banks in the study. The type of bank ownership represents the status of majority shareholders. This survey uses three main types of ownership: foreign owned banks, state-owned banks and local-owned banks. Figure 3 shows data obtained from the field regarding type of bank ownership. $40 \%$ of the banks that participated in the study were foreign owned, $32.5 \%$ had substantive government participation while $27.5 \%$ were locally owned.

In addition to the type of ownership, the study was interested in knowing institutions' listing on the stock exchange. The respondents' were asked to indicate whether the institutions were listed on the Nairobi Stock Exchange (NSE). The question was asked to establish whether the corporations listing had some relationship with its current performance. Data obtained from the field regarding the institutions' listing were analyzed and presented as shown in Figure 4. Majority, $80 \%$ of the banks that participated in the study were indeed listed on the stock exchange. Only $20 \%$ indicated that they are not listed on the Nairobi Stock Exchange.

It was also of the interest of the researcher to know the present controlling shareholders of the institutions. This question was asked in order to determine whether respondents are aware of the present controlling shareholders of the institutions in which they work for. Results from Table 1 indicate percentage scores of present controlling shareholders of the institutions. The scores range from yes $10 \%$ to $32.5 \%$. The results show that the present controlling shareholders of the three types of ownership of banks is varied. Other controlling shareholders as the study found out is that institutions such as cooperative societies $12.5 \%$ and government parastatal bodies such as the National Social Security Fund (NSSF) $10 \%$ controlled some banks.

Similarly, the researcher also sought to know the number of directors in the board who represent the controlling group. Information on number of directors in the boards of institutions under study that also represent controlling group was deemed important because it would enable in knowing whether good governance is followed in organizations. The results are as shown in Table 2. Banks had a varying representation of directors in the board who represent the controlling group. Majority, 15 percent have between $1-3$ directors in the board, $12.5 \%$ have between $4-9$ directors while only 10 percent have more than 13 directors in the board who also represent the controlling group. Hence, the researcher concluded that the institutions had varying representation in the controlling group as directors. According to generally accepted corporate governance practices, up to eleven (11) directors is the required number to make an effective board. The Central Bank of Kenya requires all institutions licensed under the Banking Act, to have at least five directors, at least three-fifths of who should be Non-Executive Directors, in order to achieve the necessary balance.

\subsection{Ownership Structure}

In order to gain an in-depth understanding of the current ownership structure in terms of share percentage of the banks under study and whether the share percentage had changed with time, the researcher asked respondents to indicate the percentage of shares owned by the state for state owned banks, managers, workers, domestic individuals, institutional and foreign investors. In the banks surveyed, though the state still had majority shares of over $70 \%$ in state-owned banks, from the findings it was evident that the state was slowly withdrawing from active participation in some banks by periodically offloading shares as some respondents noted. This may be seen as one way of encouraging other participants in owning some of its institutions hence in line with the privatisation process that the government started way back in the $90 \mathrm{~s}$. In locally-owned banks and foreign banks, share ownership varied. At least managers and workers held between $0-5$ percent of the shares each in local banks as $20 \%$ of respondents in the study noted while in foreign-owned banks employees owned up to $20 \%$ of the shares. For domestic individual investors, domestic institutional investors and foreign investors each owned up to $25 \%$ of shares. This can be termed as a move to encourage ownership of firm to other investors who are not really the owners.

\subsection{Corporate Governance Practices (CGP)}

Corporate governance practices represent the actual efforts (behaviours) of banks in implementing good corporate governance. This construct consisted of several attributes, focussing on the rules of board of directors' practices. It was noted that majority, over $60 \%$ of the respondents who participated in the study agreed that their institutions practice good corporate governance on issues such as the board of directors having regular meetings, having a clear list of the share owned by members of the board, clear internal written policy regarding board members having concurrent positions as directors in other companies, regularly formal performance appraisal review of the board, the board having effective meeting procedures firm provides equal access to information for shareholders and investment analysts and lastly, the firm publishes and distributes its financial results and management analysis. Similarly, over $50 \%$ agreed that their banks adhere to other corporate governance practices such as active monitoring of the results of the monthly 
business by the board, proper minutes records being kept and posting of financial results and management analysis on the internet. On the other hand, $62.5 \%$ disagreed to the statement indicating any potential conflicts of interest between the bank and the member of its boards exists. Agreement to the corporate governance practices may be attributed to the laid down regulatory framework and guidelines on corporate governance by the regulating body in this case the Central Bank of Kenya that govern all financial institutions registered under it.

\subsection{Bank Performance (BP)}

In this study bank performance represents the financial performance improvement. Bank performance also can be seen in comparison with the related industry as benchmark. Table 3 shows four items questions that represent bank performance. Likert scale 1 (strongly disagree) to 5 (strongly agree) was used. The questions concern managers' judgement on return on equity and its benchmarks and return on assets and its benchmarks. It can be revealed that $60 \%$ of the respondents agreed that the bank had good improvement of return on equity in the last three years. Similarly, 70\% noted that the bank had good improvement of return on assets in the last three years. As concerns the industry, $57.5 \%$ of the respondents indicated that the bank had better return on equity than industry average while $67.5 \%$ agreed that the bank had better return on assets than industry average. Hence, the researcher deduced that the banks had better performance on both return on equity and assets in the industry irrespective of the type of ownership.

\subsection{Factor Analysis Technique}

This study used factor analysis to reduce the many items that were to be considered in the corporate governance practices construct. The extracted items were then subjected to further analysis of hypothesis testing to establish whether a relationship exists between corporate governance and financial performance and type of ownership (Table 4).

\subsection{Tests of Null Hypotheses}

There were three types of relationships to be tested using one-way analysis of variance (ANOVA). In all the tests, the decision rule was if the $P$ value observed (calculated $P$ ) is less than the set alpha ( $\alpha$ ) that is the confidence level of 0.05 , then reject the null hypothesis and if the $\mathrm{P}$ value observed is greater than the set alpha of 0.05 , do not reject the null hypothesis. The testing of these hypotheses was done at level of significance of 0.05 .

\subsubsection{Null Hypothesis 1}

"There is no significant difference between banks ownership structure and corporate governance practices."

This null hypothesis was tested using one-way ANOVA. Table 4 shows the results from the test. The hypothesis stated that there is no significant difference between banks ownership structure and corporate governance practices. ANOVA test results presented in Table $5(\mathrm{P}=0.688)$ which is greater than the set alpha of 0.05 lead to failure to reject the null hypothesis. Hence the researcher concluded that there is no significant difference between banks ownership structure and corporate governance practices.

\subsubsection{Null Hypothesis 2}

"There is no significant difference between banks ownership structure and financial performance."

Null hypothesis two was tested using one-way ANOVA. Financial performances in this case are Return on Equity (ROE) and Return on Assets (ROA). The results are presented in Table 6. The results show that calculated $\mathrm{P}=0.186$ at significance level of 0.05 which is the set alpha. Since this is greater than the probability value therefore, the null hypothesis is not rejected on the basis of data obtained and concluded that there is no significant difference between banks ownership structure and financial performance.

\subsubsection{Null Hypothesis 3}

\section{"There is no significant difference between corporate governance and financial performance."}

Further on, the fourth research question sought to establish whether there is a relationship between corporate governance and performance. The results for this are presented in Table 7. From the ANOVA test of significance results presented $\mathrm{P}=$ 0.036 at 0.05 significance level indicate that there was a relationship between corporate governance practices and financial performance. Hence, the hypothesis that there is no significant difference between corporate governance and financial performance is rejected. It was then concluded that indeed there is significant difference between corporate governance and financial performance of banks.

\section{Conclusion}

It was observed that majority i.e. over $60 \%$ of the respondents who participated in the study agreed that their institutions (banks) practice good corporate governance. Thus, it is obvious that banks strive to implement good governance 
measures as stipulated by law. Sixty $(60 \%)$ percent of the respondents agreed that the bank had good improvement of return on equity in the last three years. Similarly, $70 \%$ noted that the bank had good improvement of return on assets in the last three years. It can be noted that there was an improvement in the performance of banks for the last one year irrespective of type of ownership. This implied that banks work tirelessly to perform well in the industry.Controlling shareholders of the institutions under study was varied as the study established. Similarly, the number of directors in the board representing the controlling group was varied with type of ownership. It was also seen that other banks have more than 13 directors in the board representing the controlling group though the Central Bank of Kenya financial institutions guidelines do not stipulate the maximum number of directors to be on the board. This may imply that to some extent corporate governance practices in Kenya may not be strictly followed in some firms.

\subsection{Relationship between Type of Ownership and Bank Performance}

There was an improvement in performance on return on equity (ROE) in the last three years as $60 \%$ of the respondents indicated. Similarly, 70\% noted an improvement of return on assets (ROA). Hence the researcher inferred that the banks had better performance on both return on equity and assets in the industry irrespective of the type of ownership. Further results showed that the bank performance of the three types of ownership is not varied though locally owned banks seemed to have lowest bank performance. This could mean that irrespective of type of ownership each institution tries very hard to outperform its competitor in the industry hence good results. There was also no significant difference between banks ownership structure and financial performance as the second hypothesis confirmed.

\subsection{Relationship between Type of Ownership and Corporate Governance}

The study found that there was no significant difference between type of ownership and corporate governance practices. The results confirm the first hypothesis. This may be attributed to the elaborate procedures and guidelines stipulated by the regulatory body on corporate governance that guide and govern all financial institutions registered under the Central Bank of Kenya act. Therefore, all financial institutions must adhere to it if they are to operate in the country.

\subsection{Relationship between Corporate Governance and Bank Performance}

There was significant difference between corporate governance and financial performance of different types of bank ownership. Thus, the researcher deduced that better corporate governance leads to better firm performance. This test indicates to the regulatory agencies and bank administrators that, it is necessary to consider good corporate governance to realize better corporate performance.

\section{Recommendations for Managerial Policy}

The study showed that generally in Kenya, the banking sector practiced to reasonable extent good corporation governance. However, the following recommendations are important to enhance good governance of institutions in Kenya.

Firstly, in order to implement good corporate governance, managers need to know that they should be concerned about the interrelationships between corporate governance and firm performance. The study findings strongly confirm this correlation and therefore; banks that adopt and implement good corporate governance have higher advantage of increasing their performance. More so, this will ensure that interests of the firm are served and there is easier access to funding from investors.

Secondly, there is need for the regulatory agency i.e. the Central Bank of Kenya to continue enforcing and encouraging firms to adhere to the guidelines on corporate governance for financial institutions. This can be ensured through enacting more rules and regulations thus ensuring that banks maintain confidence in shareholders and customers and give them safe level of their savings and investments.

Thirdly, evidence from the study that corporate governance has some influence on a firm's performance hence, clear policy implications should not be lost. This study recommends that corporate entities should promote corporate governance to send a positive signal to potential investors.

Fourthly, this empirical findings indicate that different types of ownership structure have similar concerns on implementing good corporate governance, the findings can be used to inform the government and other regulatory agencies that they have to be more concerned over corporations with worse corporate governance practices. In addition, the regulatory agencies including the government should promote and socialise corporate governance and its relationship to firm performance across industries.

Lastly, shareholders need to know that they have an important role in ensuring that the banks management are following and implementing good corporate governance. They can do this through establishing certain control means thus 
undertake the monitoring process. Furthermore, other stakeholders should play a more active role in ensuring good corporate governance in corporations.

\section{Suggestions for Future Research}

The study may have assumed that the efficient performance of banks' relies on corporate governance as mentioned above. However, the study does not openly rule out the fact that some other variables in the environment could be critical for firm performance. Hence, future research could usefully focus on the macroeconomic conditions necessary to promote maximum performance within the Kenyan banking system and/or other firms in other industries i.e. causes of performance differences that are not related to ownership.

\section{References}

Abor, J., \& Biekpe, N. (2007). Corporate governance, ownership structure and performance of SMEs in Ghana: implications for financing opportunities, Journal of Corporate Governance, Vol. 7, No. 3, pp. 288-300. doi:10.1108/14720700710756562, http://dx.doi.org/10.1108/14720700710756562

Agrawal, A., \& Knoeber, C., R. (1996). Firm performance and mechanism to control agency problem between managers and shareholders. Journal of Financial and Quantitative Analysis, 31(3), 377-397. doi:10.2307/2331397, http://dx.doi.org/10.2307/2331397

Akimova, I., \& Schwodiauer, G. (2004). Ownership structure, corporate governance, and enterprise performance: empirical results for Ukraine. International Advances in Economic Research. doi:10.1007/BF02295575, http://dx.doi.org/10.1007/BF02295575

Alford, H., \& Naughton, M. (2001). Managing as if Faith Mattered, Notre Dame: University of Notre Dame Press.

Becht, Marco, Bolton P., and Roell A. (2000). Corporate Governance and Control. ECGI Working Paper Series in Finance, No. 002/2002, Bruxelles: European Corporate Governance Institute.

Bennedsen, M., \& Wolfenzon, D. (2000). The balance of power in closely held corporations. Journal of Financial

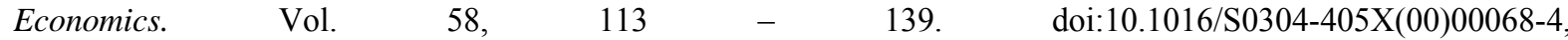
http://dx.doi.org/10.1016/S0304-405X(00)00068-4

Blair, M. (1995). Ownership and Control: Rethinking Corporate Governance for the twenty-first century. The Brookings Institution.

Brown, J. D. (2002). Statistics Corner. Questions and answers about language testing statistics: The Cronbach alpha reliability estimate. [Online] Shiken: JALT Testing \& Evaluation SIG Newsletter, 6 (1), 16-18. Available: http://www.jalt.org/test/bro_9.htm.

Capital Markets Authority of Kenya. (2000). Guidelines on corporate governance practices by public Listed Companies. The Capital Markets Act: Gazette Notice No. 3362. Government of Kenya.

Central Bank of Kenya, (2006). Prudential guidelines for institutions licensed under the Banking Act. [Online] Central Bank of Kenya. pp. 27-48. Available: http://www.centralbank.go.ke

Central Bank of Kenya, (2007). Annual report 2008. [Online] Available: http://www.centralbank.go.ke.

Central Bank of Kenya, (2008). Banking supervision Annual report 2008. [Online] Available: http://www.centralbank.go.ke.

Central Bank of Kenya, (2009). Annual report. [Online] Available: http://www.centralbank.go.ke.

Centre for Corporate Governance. (2004). A study of corporate governance practices in the commercial banking sector in Kenya. Centre for Corporate Governance.

Centre for European Policy Studies. (1995). Corporate governance in Europe. CEPS Working Party Report, No. 12, Bruxelles, Centre for European Policy Studies.

Claessens, C., and Jansen, M. (2000). The Internationalization of Financial Services: Issues and Lessons for Developing Countries. Dordrecht, Holland: Kluwer.

Claessens, S., Djankov, Fan S. J. P. H., \& Lang. L. H. P. (2002). Disentangling the Incentives and Entrenchment Effects of Large Shareholdings. Journal of Finance, V57 (6), 2741-2771. doi:10.1111/1540-6261.00511, http://dx.doi.org/10.1111/1540-6261.00511 
Coleman, A. K. (2007). Relationship between corporate governance and firm performance: an African perspective. [Online] University of Stellenbosch-South Africa. Available: http://etd.sun.ac.za/handle/10019/664

Coolican, H. (1996). Introduction to research methods and statistics in psychology. ( $2^{\text {nd }}$ ed). London: Hodder \& Stoughton.

Cvelbar, L. K., \& Mihalic, T. (2007). Ownership structure as a corporate governance mechanism [Online] Available: hrcak.srce.hr/file/34489

Denis, D. K., \& McConnell, J. J. (2003). International Corporate Governance. ECGI Finance Working Paper, No. 5, Bruxelles: European Corporate Governance Institute.

Denis, D. K., \& McConnell, J. J., (2002). International Corporate Governance: A survey. [Online] Available: mba.tuck.dartmouth.edu/ccg/PDFs/2002Conference/DenisMcConnell.pdf

DesJardins \& McCall, J. (2005). A Stakeholder Theory of the Modern Corporation: Kantian Capitalism, in Contemporary Issues in Business Ethics ( $4^{\text {th }}$ ed.). Belmont, CA: Wadsworth

Dicke, L., A. (2000). Accountability in human services contracting: stewardship theory and the internal perspective. University of Utah. [Online] Available: http://sunzil.lib.hku.hk/ER/detail/hkul/3161846

Donaldson, L., \& Davis, J. H. (1991). Stewardship theory or agency theory? CEO governance and shareholder returns. Australian Journal of Management, Vol. 30, pp. 25 - 34.

Faccio, M., \& Lang, L. H. P. (2002). The Ultimate Ownership of Western European Corporations. Journal of Financial Economics, 65(3), 365-395. doi:10.1016/S0304-405X(02)00146-0, http://dx.doi.org/10.1016/S0304-405X(02)00146-0

Figueira, C., Nellis, J., \& Parker, D. (2007). Does Ownership affect the efficiency of banks? The Journal of Developing Areas 40(1), pp. 37-62. doi:10.1353/jda.2007.0004, http://dx.doi.org/10.1353/jda.2007.0004

Freeman, R. E., Wicks, C. A. \& Parmar, B. (2004). Stakeholder theory and the corporate objective revisited. Organization Science, 15(3), 364 - 369. doi:10.1287/orsc.1040.0066, http://dx.doi.org/10.1287/orsc.1040.0066

Gichure, C. W. (2008). Ethics for Africa today: An introduction to business ethics. Pauline Publications Africa: Nairobi.

Han, Ki C L., Suk, H. S., \& David Y. (1999). Ownership structure and firm performance: International evidence. Multinational Business Review.

Holderness, C. G. (2009). The Myth of diffuse ownership in the United States. Review of Financial studies, 22(4), pp. 1377- 1408. doi:10.1093/rfs/hhm069, http://dx.doi.org/10.1093/rfs/hhm069

Jensen, M., \& Meckling, W. (1976). Theory of the firm: Managerial behavior, agency costs and ownership structure. Journal of Financial Economics, 3, pp.305-360. doi:10.1016/0304-405X(76)90026-X, http://dx.doi.org/10.1016/0304-405X(76)90026-X

Jiang, P. (2004). Relationship between Ownership Structure and Firm Performance. Nature and Science, 2(4). [Online] Available: http://www.sciencepub.org.

Kamau, A. (2009). Efficiency and Productivity of the Banking Sector in Kenya: An Empirical Investigation. University of Nairobi.

Kapopoulos, P., \& Lazaretou, S. (2006). Corporate ownership structure and firm performance: Evidence from Greek firms. Working Paper No. 37, Bank of Greece: Economic Research Department - Special Studies Division.

Kenya Bankers Association. (2008). Bank Performance and Rankings.

Kerliger, F. N., \& Lee, H. B. (2000). Foundations of behavioural research (4 ${ }^{\text {th }}$ ed.). Fort Worth: Harcourt College Publishers.

Klapper, L. F., and Love, I. (2002). Corporate governance, investor protection and performance in emerging markets. World Bank Policy Research Paper 2818. [Online] Available: http://www-wds.worldbank.org

La Porta, R., Lopez-de-Silanes F., Shleifer A., and Vishny R., (2000). "Investor Protection and Corporate Valuation", Journal of Finance, Vol. 57, pp. 1147-1170. doi:10.1111/1540-6261.00457, http://dx.doi.org/10.1111/1540-6261.00457

La Porta, R., Lopez-de-Silanes F., Shleifer A., and Vishny R., (2002). "Investor Protection and Corporate Governance", Journal of Financial Economics, Vol. 58, pp. 3-27. doi:10.1016/S0304-405X(00)00065-9 http://dx.doi.org/10.1016/S0304-405X(00)00065-9 
Lang, L. H. P. \& So, R. W. (2002). Bank ownership structure and economic performance, working paper, Department of Finance, Chinese University of Hongkong. Shatin: Hong Kong.

Lefort, Fernando, and Eduardo, Walker, (1999). Ownership and capital structure of Chilean conglomerates: Facts and hypotheses for governance. Revista ABANTE, Vol 3(1), 3-27.

Maher, M., \& Anderson, T. (1999). Corporate governance: effects on firm performance and economic growth. Organization for Economic Cooperation and Development, Paris.

Mallin, C. (2007). Corporate governance ( $2^{\text {nd }}$ ed.). Oxford University Press: Oxford.

Mason, E. J., \& Bramble, W. J. (1997). Research in education and behavioural sciences. Dubuque: Brown \& Benchmark Publishers.

McConnell, J. J., \& Servaes, H. (1990). Additional Evidence on Equity Ownership and Corporate Value. Journal of Financial Economics, 27(2), 595-612. doi:10.1016/0304-405X(90)90069-C, http://dx.doi.org/10.1016/0304-405X(90)90069-C

Mugenda, O. M., \& Mugenda, A. G. (2003). Research methods: Quantitative and qualitative approaches. Nairobi: Acts Press.

Mwangi, A. K. G. (2002). A survey of Corporate Governance Practices Among Insurance Companies in Kenya. University of Nairobi Press - Nairobi.

Mwega, M., F. (2009). Global Financial Crisis Discussion Series Paper 7: Kenya. School of Economics, University of Nairobi.

Nambiro, C. A. (2007). Relationship between level of implementation of CMA guidelines on corporate governance and profitability of companies listed at the Nairobi Stock Exchange. University of Nairobi Press - Nairobi.

Organization for Economic Cooperation and Development. (2004). Principles of Corporate Governance. Paris.

Oyejide, T. A., \& Soyibo, A. (2001, January). Corporate Governance in Nigeria. Paper presented at the conference on corporate governance. Accra, Ghana.

Sanda, A., Mikailu, S. A., \& Garba, T. (2005). Corporate governance mechanisms and firm financial performance in Nigeria. African Economic Research Consortium (AERC) Research Paper 149, AERC: Nairobi.

Shirley, M. and Walsh, P. (2001). Public vs. Private Ownership. World Bank Policy Research Working Paper No. 2420. Washington, D.C.: USA.

Stiles, P., \& Taylor, B. (2001). Boards at work: How directors view their roles and responsibilities. Strategic Management Journal, 20 (12), 1087-1108.

Tandelilin, E., Kaaro, H., Mahadwartha, P. A., \& Supriyatna. (2007). Corporate governance, risk management and bank performance: Does Type of Ownership matter? EADN Working Paper No. 34.

Valadares, S. M., \& Leal R. (2000). Ownership and control structure of Brazilian companies. Working paper, Universidade Federal do Rio de Janeiro.

Wambua, (1999). Corporate governance practices in the banking sub-sector in Kenya. University of Nairobi..

Williamson, O. E. (1999). "Strategy Research: Governance and Competence Perspectives" Strategic Management Journal. $\quad$ Vol. 20

doi:10.1002/(SICI)1097-0266(199912)20:12<1087::AID-SMJ71>3.3.CO;2-Q, http://dx.doi.org/10.1002/(SICI)1097-0266(199912)20:12<1087::AID-SMJ71>3.3.CO;2-Q

Zhuang, J. (1999). Some conceptual issues of corporate governance. EDRC Briefing Notes Number 13 [Online] Available: ww.adb.org/Documents/Books/Corporate_Governance/Vol1/chapter2.pdf. 
Table 1. Present Controlling Shareholders

\begin{tabular}{|l|c|c|c|c|c|c|c|}
\hline & State & Individual & $\begin{array}{c}\text { Managers/ } \\
\text { Directors }\end{array}$ & Employees & Family & $\begin{array}{c}\text { Subsidiary of } \\
\text { Multinational }\end{array}$ & Others \\
\hline Yes & 25.0 & 32.5 & 25.0 & 32.5 & 10.0 & 27.5 & 12.5 \\
\hline No & 25.0 & 45.0 & 52.5 & 47.5 & 57.5 & 45.0 & 10.0 \\
\hline No Response & 50.0 & 22.5 & 22.5 & 20.0 & 32.5 & 27.5 & 77.5 \\
\hline Total & 100 & 100 & 100 & 100 & 100 & 100 & 100 \\
\hline
\end{tabular}

Table 2. Number of Directors in the Board who represent the Controlling Group

\begin{tabular}{|l|c|c|}
\hline No of Directors & Frequency & Percent \\
\hline $1-3$ & 6 & 15.0 \\
\hline $4-6$ & 5 & 12.5 \\
\hline $7-9$ & 5 & 12.5 \\
\hline $13+$ & 4 & 10.0 \\
\hline Not stated & 20 & 50.0 \\
\hline Total & 40 & 100.0 \\
\hline
\end{tabular}

Table 3. Bank Performance

\begin{tabular}{|c|c|c|c|c|c|c|c|}
\hline Code & Item & $\begin{array}{c}\text { Strongly } \\
\text { Agree }\end{array}$ & Agree & $\begin{array}{c}\text { Neither } \\
\text { Agree nor } \\
\text { Disagree }\end{array}$ & Disagree & $\begin{array}{c}\text { Strongly } \\
\text { Disagree }\end{array}$ & $\begin{array}{c}\text { Not } \\
\text { Stated }\end{array}$ \\
\hline BP_12a & $\begin{array}{c}\text { The bank has good improvement } \\
\text { of return on equity in the last } \\
\text { three years }\end{array}$ & $\begin{array}{c}15 \\
(37.5)\end{array}$ & $\begin{array}{c}9 \\
(22.5)\end{array}$ & $\begin{array}{c}9 \\
(22.5)\end{array}$ & $\begin{array}{c}(2.5) \\
(7.5)\end{array}$ & $\begin{array}{c}3 \\
(7.5)\end{array}$ \\
\hline BP_12b & $\begin{array}{c}\text { The bank has good improvement } \\
\text { of return on assets in the last } \\
\text { three years }\end{array}$ & $\begin{array}{c}15 \\
(37.5)\end{array}$ & $\begin{array}{c}13 \\
(32.5)\end{array}$ & $\begin{array}{c}8 \\
(20.0)\end{array}$ & - & 1 & 3 \\
\hline BP_12c & $\begin{array}{c}\text { The firm has better return on } \\
\text { equity than industry average } \\
\text { (benchmarks) }\end{array}$ & $\begin{array}{c}9 \\
(22.5)\end{array}$ & $\begin{array}{c}14 \\
(35.0)\end{array}$ & $\begin{array}{c}(22.5) \\
(7.5)\end{array}$ \\
\hline BP_12d & $\begin{array}{c}\text { The firm has better return on } \\
\text { assets } \begin{array}{c}11 \\
\text { than industry average } \\
\text { (benchmarks) }\end{array}\end{array}$ & $\begin{array}{c}16 \\
(27.5)\end{array}$ & $\begin{array}{c}(40.0) \\
(12.5)\end{array}$ & $\begin{array}{c}(5.0) \\
(5.0)\end{array}$ & $\begin{array}{c}(7.5) \\
(7.5)\end{array}$ & $\begin{array}{c}(7.5) \\
(7.5)\end{array}$ \\
\hline
\end{tabular}


Table 4. The results of explanatory factor analysis on corporate governance items

\begin{tabular}{|c|c|c|c|c|}
\hline \multirow[t]{2}{*}{ Rotated Component Matrix } & \multicolumn{4}{|c|}{ Component } \\
\hline & $\begin{array}{l}\text { Governance } \\
\text { framework }\end{array}$ & $\begin{array}{l}\text { Communication and } \\
\text { evaluation strategies }\end{array}$ & $\begin{array}{c}\text { Code of } \\
\text { conduct } \& \\
\text { best practice }\end{array}$ & $\begin{array}{c}\text { Directors' } \\
\text { rewards }\end{array}$ \\
\hline BoD minutes are minuted & .905 & & & \\
\hline $\begin{array}{l}\text { The bank has a clear list of the share owned by } \\
\text { members of the BoD }\end{array}$ & .852 & & & \\
\hline $\begin{array}{l}\text { The BoD has effective meeting procedures (i.e. } \\
\text { meeting agendas distributed in advance) }\end{array}$ & .766 & & & \\
\hline $\begin{array}{l}\text { The BoD actively monitors the results of the } \\
\text { monthly business }\end{array}$ & .763 & & & \\
\hline $\begin{array}{l}\text { The BoD is responsible to the vision and mission, } \\
\text { business plan and strategic plan }\end{array}$ & .742 & & & \\
\hline $\begin{array}{l}\text { The bank has clear internal written policy on } \\
\text { regarding BoD members having concurrent } \\
\text { positions as directors in other companies }\end{array}$ & .729 & & & \\
\hline $\begin{array}{l}\text { The audit section of the firm is performing its } \\
\text { duties as expected }\end{array}$ & & .867 & & \\
\hline $\begin{array}{l}\text { The firm publishes and distributes its financial } \\
\text { results and management analysis }\end{array}$ & & .820 & & \\
\hline $\begin{array}{l}\text { The firm provides equal access to information for } \\
\text { shareholders and investment analysts }\end{array}$ & & .819 & & \\
\hline The Board of Directors has regular meetings & .592 & .681 & & \\
\hline $\begin{array}{l}\text { The firm posts its financial results and } \\
\text { management analysis on the internet }\end{array}$ & & .664 & & \\
\hline $\begin{array}{l}\text { The bank provides formal performance appraisal } \\
\text { review of the BoD regularly }\end{array}$ & & 612 & & \\
\hline $\begin{array}{l}\text { The bank regularly holds self-assessment of good } \\
\text { corporate governance }\end{array}$ & & .560 & & \\
\hline Stock options & & & .848 & \\
\hline $\begin{array}{l}\text { The firm track changes in its ownership structure } \\
\text { so that any and all voting shareholders are known }\end{array}$ & & & .709 & \\
\hline $\begin{array}{l}\text { Shareholders rights and responsibilities are well } \\
\text { adhered to; e.g. rights to vote, } 28 \text { days notice of } \\
\text { their meetings, etc. }\end{array}$ & & & .627 & \\
\hline Bonus dependent on performance & & & .622 & \\
\hline $\begin{array}{l}\text { The bank has well written Corporate Governance } \\
\text { Policies; e.g. which covers specification on BoDs } \\
\text { duties, disclosure rules, shareholders rights etc. } \\
\text { Revealed code of conduct/ethics clearly }\end{array}$ & & & .597 & \\
\hline $\begin{array}{l}\text { The following type of compensation are sufficient } \\
\text { to Directors: Salary Independent of Performance }\end{array}$ & & & & .785 \\
\hline $\begin{array}{l}\text { There are any potential conflicts of interest } \\
\text { between the bank and the member of its BoD }\end{array}$ & & & & .635 \\
\hline
\end{tabular}

Extraction Method: Principal Component Analysis. Rotation Method: Varimax with Kaiser Normalization.

A Rotation converged in 7 iterations. 
Table 5. ANOVA Tests for difference in Corporate Governance Practices of different Types of Ownership of Banks

\begin{tabular}{|l|c|c|c|c|c|}
\hline Source & Sum of Squares & df & Mean Square & F & Sig. \\
\hline Between Groups & 1.018 & 2 & .509 & .377 & .688 \\
\hline Within Groups & 49.925 & 37 & 1.349 & & \\
\hline Total & 50.944 & 39 & & & \\
\hline
\end{tabular}

Table 6. ANOVA Tests for difference in Financial Performance of different Types of Ownership

\begin{tabular}{|l|c|c|c|c|c|}
\hline Source & Sum of Squares & df & Mean Square & F & Sig. \\
\hline Between Groups & 6.946 & 2 & 3.473 & 1.759 & .186 \\
\hline Within Groups & 73.053 & 37 & 1.974 & & \\
\hline Total & 79.998 & 39 & & & \\
\hline
\end{tabular}

Table 7. ANOVA Tests for difference in Corporate Governance Practices and Financial Performance

\begin{tabular}{|l|c|c|c|c|c|}
\hline Source & Sum of Squares & df & Mean Square & F & Sig. \\
\hline Between Groups & 46.907 & 15 & 3.127 & 2.268 & .036 \\
\hline Within Groups & 33.092 & 24 & 1.379 & & \\
\hline Total & 79.998 & 39 & & & \\
\hline
\end{tabular}




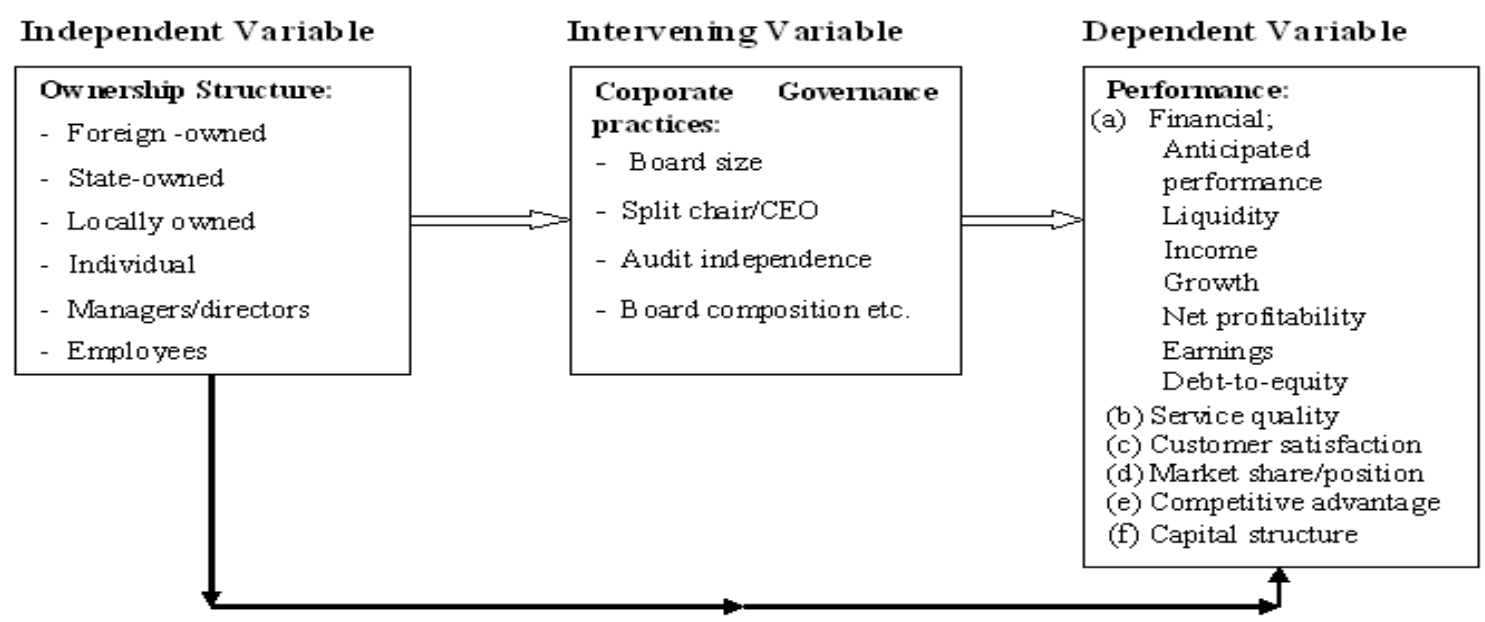

Direct effect of Ownership Structure on Performance

Figure 1. Conceptual Framework on the effects of ownership structure on corporate governance and performance.

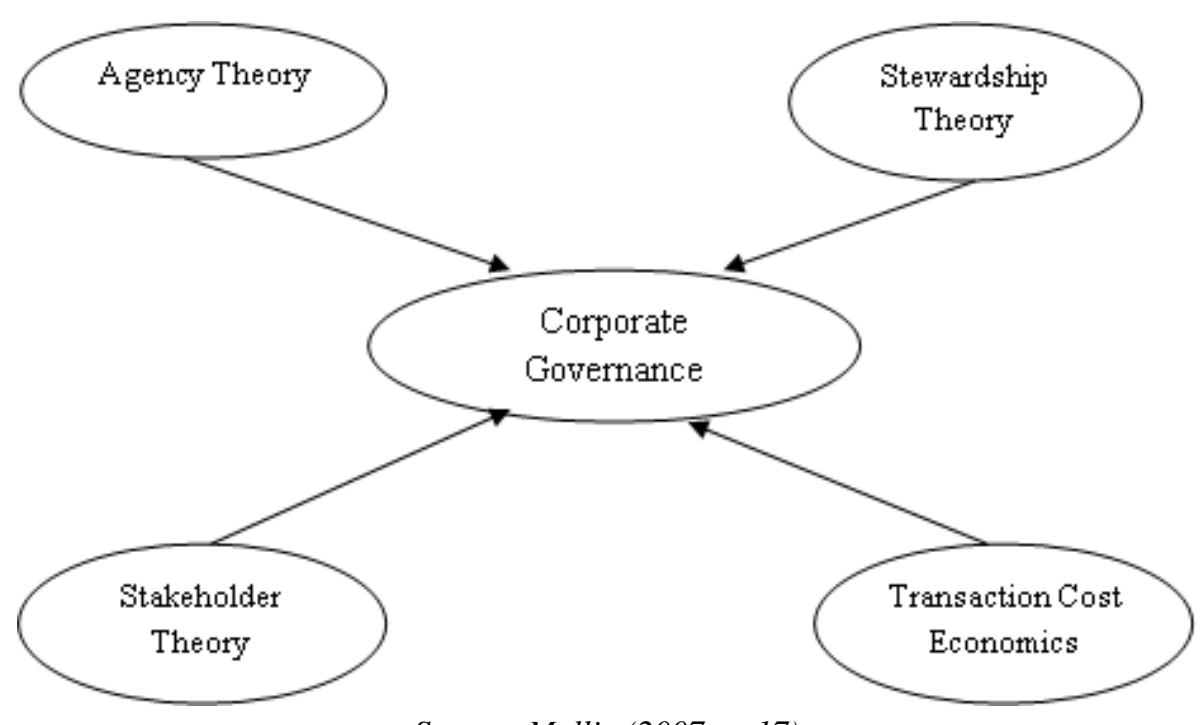

Source: Mallin (2007, p. 17)

Figure 2. Main Theories influencing Corporate Governance Development. 


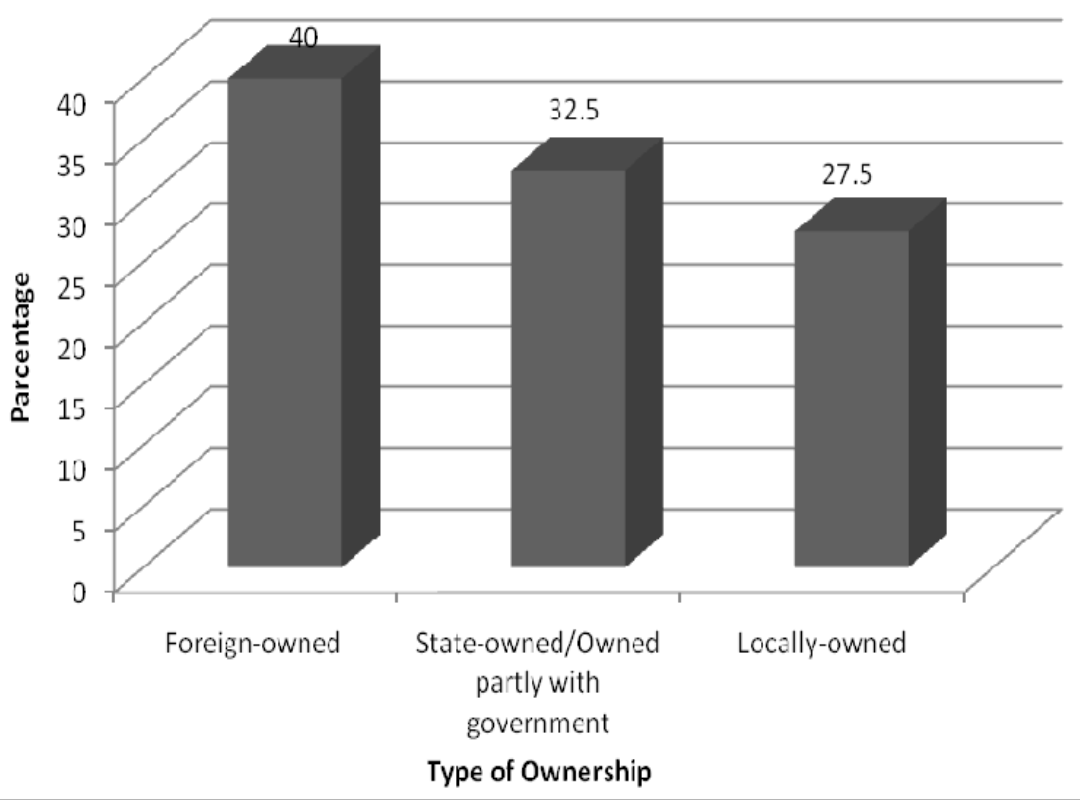

Figure 3. Type of Bank Ownership

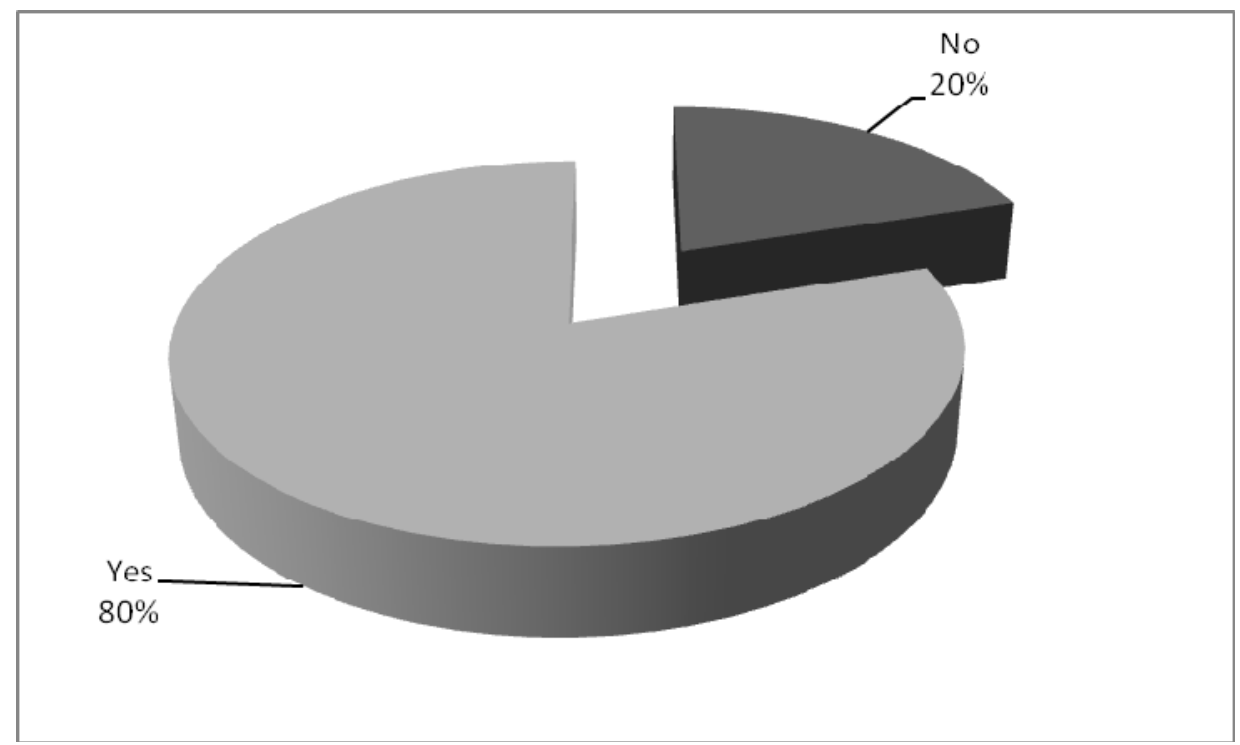

Figure 4. Stocks Listing of the Institutions 